\title{
Effect of PGRs on Growth, Yield and Quality of Coriander (Coriandrum sativum L.) cv. NRCSS-Acr-1
}

\author{
Amit Kumar Kurmi ${ }^{1 *}$, I.S. Naruka ${ }^{1}$, S.S. Kushwah ${ }^{2}$ and G.S. Chouhan ${ }^{2}$ \\ ${ }^{1}$ Department of Plantation, Spices, Medicinal and Aromatic Crops, \\ ${ }^{2}$ Department of Vegetable Science, College of Horticulture, Mandsaur-458 001, \\ Madhya Pradesh, India \\ *Corresponding author
}

\begin{tabular}{|c|c|}
\hline & A B S T R A C T \\
\hline $\begin{array}{l}\text { K e y w o r d s } \\
\text { Coriander, PGRs, } \\
\text { Growth, Yield, } \\
\text { Quality, Economics } \\
\text { of treatment }\end{array}$ & \multirow{3}{*}{ 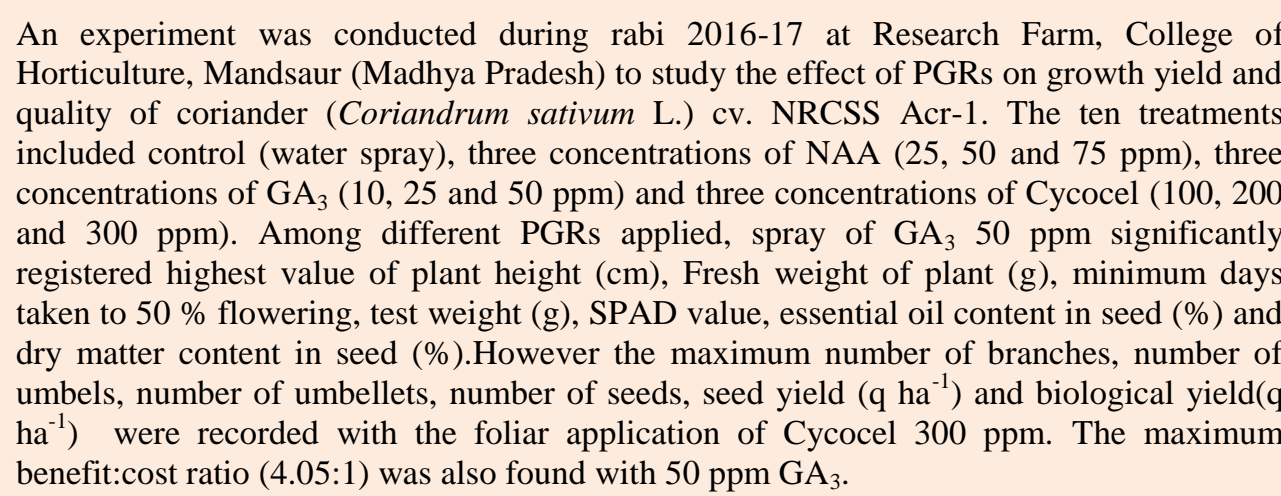 } \\
\hline Article Info & \\
\hline $\begin{array}{l}\text { Accepted: } \\
\text { 17 April } 2019 \\
\text { Available Online: } \\
10 \text { May } 2019\end{array}$ & \\
\hline
\end{tabular}

\section{Introduction}

Coriander (Coriandrum sativum L.) popularly known as "Dhania" is one of the oldest and most widely used seed spice crop by entire mankind of the world. It is a thin-stemmed, small bushy herb, much branched and grows about 25 to $50 \mathrm{~cm}$ tall, with alternate and compound leaves become highly segmented and linear as they reach upper extremities. Inflorescence is a compound umbel and usually comprises about five smaller umbellets. Fruits are globular, yellow brown when ripened and are 3 to $4 \mathrm{~mm}$ in diameter. The fruits consist of two halves, the single seeded mericarps. The fruits have a fragrant odour and pleasant aromatic taste. The odour and taste are due to the compound containing d-linalool or coriandrol. Coriander is used as a spice, in culinary, medicine and in perfumery, food, beverage and pharmaceuticals industries. The dried ground fruits are the major ingredient of the curry powder. The whole fruits are also used to 
flavour foods like pickles, sauces and confectionary. The seed contain 18-21 per cent fatty oil which is used in the cosmetic industries. The young plants as well as the leaves are used in the preparation of chutney and are also used as seasoning in curries, soups and sauces.

Use of plant growth regulators may be one of the best possible way in affecting production and productivity as they provide an immediate impact on crop improvement programmes and are less time consuming. Gibberellic acid is found to induce stem and internode elongation, flowering and fruit setting and growth. Application of naphthalic acetic acid (NAA) is also known to induce higher physiological efficiency including photosynthetic ability of plants. Plant growth regulators leads also to better growth and yield without substantial increase in the cost of production. Therefore standardizations of levels of growth regulators determine the growth, yield and quality of coriander (Haokip et al., 2016).

\section{Materials and Methods}

An experiment was conducted during rabi 2016-17 at Research Farm, College of Horticulture, Mandsaur (Madhya Pradesh) to see the effect of different plant growth regulators on growth, yield and quality of coriander. The soil of experimental field was light black loamy in texture, with $7.2 \mathrm{pH}$, low in available nitrogen $(243.2 \mathrm{~kg} / \mathrm{ha})$, medium in available phosphorus (19.75 $\mathrm{kg} / \mathrm{ha})$ and high in available potassium (448.0 kg/ha). The ten treatments tested include control (water spray), three concentrations of NAA (25, 50 and $75 \mathrm{ppm})$, three concentrations of GA3 (10, 25 and $50 \mathrm{ppm})$ and three concentrations of Cycocel (100, 200 and 300 $\mathrm{ppm})$. These treatments were tested in randomized block design with three replications. The seed of coriander cultivar
NRCSS Acr -1 was sown on $20^{\text {th }}$ October, 2016 keeping a row spacing of $30 \mathrm{~cm}$ and the crop was harvested on $05^{\text {th }}$ March, 2017. The crop was fertilized with NPK @ 60:40:30kg $\mathrm{ha}^{-1}$ as basal dose. Growth regulators were applied at 30 DAS as foliar spray as per treatments and untreated plots were sprayed with water. The economics of treatment was calculated on the basis of prevailing market rates.

\section{Results and Discussion}

\section{Growth attributes}

The results revealed that application of PGRs significantly improve vegetative growth of coriander. Among different PGRs applied, 50 ppm $\mathrm{GA}_{3}$ recorded significantly maximum plant height at 40 DAS $(19.53 \mathrm{~cm}), 60$ DAS $(54.73 \mathrm{~cm})$ and at harvest $(122.70 \mathrm{~cm})$ fresh weight of plant at 40 DAS (15.80 g), 60 DAS $(57.60 \mathrm{~g})$, at harvest (46.34 g) and decreased the days to 50 percent flowering (79.33 days). Treatment CCC 300 ppm exhibited minimum influence with respect to plant height at 40 DAS $(10.07 \mathrm{~cm}), 60$ DAS $(38.80 \mathrm{~cm})$ and at harvest $(103.13 \mathrm{~cm})$ whereas the control (water spray) exhibited maximum days to 50 percent flowering (93.33 days) and minimum fresh weight of plant at 40 DAS $(10.97 \mathrm{~g})$, 60DAS (40.07 g), at harvest (30.08 g).

The 50 ppmGA $_{3}$ treatment was found to be more effective for influencing the vegetative growth as evaluated by various parameters. The increase in vegetative growth seems to be due to enhanced cell division and cell enlargement. Promotion of protein synthesis by $\mathrm{GA}_{3}$ application exogenously might have resulted in enhanced vegetative growth. Similar results were reported by Singh et al., (2012) in coriander, Gour et al., (2010), Bairva et al., (2012) in fenugreek and Abbas (2013) in dill (Table 1). 
Table.1 Effect of PGRs on growth attributes of coriander

\begin{tabular}{|c|c|c|c|c|c|c|c|c|}
\hline \multirow[t]{2}{*}{ treatment } & \multicolumn{3}{|c|}{ Plant height (cm) } & \multicolumn{3}{|c|}{ Fresh weight of plant (g) } & \multirow{2}{*}{$\begin{array}{c}\text { Number of } \\
\text { branches } \\
\text { plant }^{-1} \\
\text { At harvest }\end{array}$} & \multirow{2}{*}{$\begin{array}{c}\text { Days to } 50 \\
\text { percent } \\
\text { flowering }\end{array}$} \\
\hline & 40 DAS & 60 DAS & At harvest & $40 \mathrm{DAS}$ & $60 \mathrm{DAS}$ & At harvest & & \\
\hline $\mathbf{T}_{1}-$ Control & 11.53 & 43.07 & 108.30 & 10.97 & 40.07 & 30.08 & 5.17 & 93.33 \\
\hline T & 12.63 & 45.05 & 109.53 & 11.50 & 47.37 & 35.14 & 5.70 & 86.33 \\
\hline $\mathbf{T}_{3}-\mathbf{N A A} @ \mathbf{5 0} \mathbf{p p m}$ & 13.50 & 45.83 & 112.37 & 12.20 & 49.87 & 37.37 & 5.80 & 84.67 \\
\hline T4-NAA@75 ppm & 17.47 & 50.23 & 118.97 & 14.30 & 53.93 & 42.98 & 6.27 & 82.67 \\
\hline $\mathbf{T}_{5}-\mathbf{G A} \mathbf{A}_{3} @ 10$ ppm & 14.10 & 46.63 & 114.43 & 12.03 & 50.20 & 36.17 & 5.77 & 85.67 \\
\hline $\mathbf{T}_{6}-\mathbf{G A}_{3} @ 25 \mathrm{ppm}$ & 15.50 & 47.07 & 115.33 & 12.73 & 51.07 & 39.74 & 5.87 & 84.00 \\
\hline $\mathbf{T}_{7}-\mathbf{G A} \mathbf{A}_{3} @ \mathbf{5 0} \mathbf{p p m}$ & 19.53 & 54.73 & 122.70 & 15.80 & 57.60 & 46.34 & 6.77 & 79.33 \\
\hline $\mathbf{T}_{8}-$ Cycocel @ 100 ppm & 10.77 & 42.27 & 105.57 & 11.13 & 44.77 & 34.49 & 6.30 & 91.00 \\
\hline T9-Cycocel @ 200 ppm & 10.23 & 40.93 & 104.30 & 11.60 & 47.33 & 36.87 & 6.37 & 89.67 \\
\hline $\mathbf{T}_{10}-$ Cycocel @ 300 ppm & 10.07 & 38.80 & 103.13 & 11.93 & 48.20 & 37.15 & 7.20 & 89.33 \\
\hline S.Em. \pm & 0.5379 & 1.0513 & 1.084 & 0.4582 & 0.9443 & 1.0636 & 0.1258 & 0.3635 \\
\hline C.D. at $5 \%$ & 1.5983 & 3.1235 & 3.2208 & 1.3615 & 2.8056 & 3.1602 & 0.3736 & 1.0799 \\
\hline
\end{tabular}


Table.2 Effect of PGRs on yield attributes and quality attributes of coriander

\begin{tabular}{|c|c|c|c|c|c|c|c|c|c|c|c|}
\hline Treatment & $\begin{array}{c}\begin{array}{c}\text { Number } \\
\text { of } \\
\text { umbels }\end{array} \\
\text { plant }^{-1}\end{array}$ & $\begin{array}{c}\begin{array}{c}\text { Number } \\
\text { of } \\
\text { umbellets } \\
\text { umbel }^{-1}\end{array} \\
\end{array}$ & $\begin{array}{l}\text { Number } \\
\text { of seed } \\
\text { umbel }^{-1}\end{array}$ & $\begin{array}{c}\text { Test } \\
\text { weight } \\
\text { (g) }\end{array}$ & $\begin{array}{l}\text { Seed } \\
\text { yield } \\
(\mathbf{q} \\
\left.\mathbf{h a}^{-1}\right)\end{array}$ & $\begin{array}{l}\text { Biological } \\
\text { yield }(\mathbf{q} \\
\left.\text { ha }^{-1}\right)\end{array}$ & $\begin{array}{l}\text { Harvest } \\
\text { index } \\
(\%)\end{array}$ & $\begin{array}{l}\text { SPAD } \\
\text { value }\end{array}$ & $\begin{array}{c}\text { Essential } \\
\text { oil } \\
\text { content } \\
\text { in seed } \\
(\%)\end{array}$ & $\begin{array}{c}\text { Dry } \\
\text { matter } \\
\text { content } \\
\text { in seed } \\
(\%)\end{array}$ & $\begin{array}{l}\text { Benefit: } \\
\text { cost } \\
\text { ratio }\end{array}$ \\
\hline $\mathbf{T}_{1}-$ Control & 26.40 & 4.93 & 33.07 & 9.56 & 11.17 & 34.62 & 32.33 & 37.67 & 0.33 & 80.14 & $3.10: 1$ \\
\hline $\mathbf{T}_{2}-\mathbf{N A A} @ 25$ ppm & 31.60 & 6.20 & 35.43 & 10.03 & 11.85 & 35.83 & 35.95 & 40.27 & 0.34 & 84.72 & $3.26: 1$ \\
\hline $\mathbf{T}_{3}$-NAA@ 50 ppm & 32.53 & 6.40 & 36.93 & 11.28 & 13.28 & 37.53 & 38.01 & 41.06 & 0.43 & 85.78 & $3.68: 1$ \\
\hline $\mathbf{T}_{4}-\mathrm{NAA} @ 75$ ppm & 34.73 & 7.03 & 41.27 & 12.05 & 14.26 & 40.32 & 37.79 & 42.25 & 0.47 & 88.01 & $3.93: 1$ \\
\hline $\mathbf{T}_{5}-\mathbf{G A}_{3} @ 10$ ppm & 32.73 & 6.53 & 36.20 & 11.65 & 13.36 & 39.17 & 36.74 & 41.33 & 0.44 & 85.96 & $3.73: 1$ \\
\hline $\mathbf{T}_{6}-\mathbf{G A}_{3} @ 25$ ppm & 34.27 & 6.80 & 40.07 & 11.90 & 14.15 & 38.97 & 38.89 & 41.51 & 0.45 & 86.24 & $3.76: 1$ \\
\hline $\mathbf{T}_{7}-\mathbf{G A} 3 \mathbf{A}_{3} @ 50$ ppm & 39.47 & 7.33 & 46.47 & 12.95 & 16.27 & 43.96 & 36.99 & 45.08 & 0.51 & 90.80 & $4.05: 1$ \\
\hline $\begin{array}{l}\mathbf{T}_{8}-\text { Cycocel @ } 100 \\
\text { ppm }\end{array}$ & 36.00 & 7.20 & 43.93 & 10.37 & 15.48 & 43.25 & 35.76 & 37.95 & 0.33 & 82.57 & $3.84: 1$ \\
\hline $\begin{array}{l}\text { T9-Cycocel @ } 200 \\
\text { ppm }\end{array}$ & 36.07 & 7.27 & 45.73 & 10.91 & 15.69 & 43.72 & 35.89 & 38.43 & 0.35 & 84.44 & $3.27: 1$ \\
\hline $\begin{array}{l}\mathbf{T}_{10}-\text { Cycocel @ } 300 \\
\text { ppm }\end{array}$ & 42.93 & 7.87 & 49.60 & 11.27 & 18.20 & 47.03 & 38.71 & 40.38 & 0.36 & 85.63 & $3.39: 1$ \\
\hline S.Em. \pm & 1.1173 & 0.1556 & 0.9274 & 0.298 & 0.638 & 0.9851 & 1.3256 & 0.8079 & 0.0131 & 0.8796 & $3.10: 1$ \\
\hline C.D. at $5 \%$ & 3.3198 & 0.4623 & 2.7555 & 0.887 & 1.898 & 2.92 & NS & 2.400 & 0.0388 & 2.6133 & $3.26: 1$ \\
\hline
\end{tabular}


Treatment CCC $300 \mathrm{ppm}$ recorded the maximum number of branches plant ${ }^{-1}$ (7.20) while the minimum number of branches plant $^{-1}$ (5.17) was recorded in $T_{1}$ (control). The increase in number of primary branches could be due to suppression of apical dominance by the application of growth retardant Cycocel which diverts the polar transport of auxin towards the basal buds there by leads to increased branching. These results were in conformation with Vaidehi et al., (2015), Haokip et al., (2016), Yugandhar et al., (2016) in coriander, Bairva et al., (2012) in fenugreek and Rohamare et al., (2013) in Ajwain.

\section{Yield and yield attributes parameters}

The results revealed that application of PGRs significantly improve yield and yield attributes parameters of coriander except harvest index (\%). Among different PGRs applied, 300 ppm CCC recorded significantly maximum number of umbels plant ${ }^{-1}$ (42.93) number of umbellets per umbel $^{-1}$ (7.87) number of seed umbel $^{-1}$ (49.60) seed yield (18.20q ha ${ }^{-1}$ ) biological yield (47.03q ha $\left.{ }^{-1}\right)$. Among various PGRs used in the present study the control (water spray) exhibited minimum number of umbels plant ${ }^{-1}$ (26.40) number of umbellets umbel $^{-1}$ (4.93) number of seed umbel $^{-1}$ (33.07) seed yield (11.17q $\left.\mathrm{ha}^{-1}\right)$ biological yield $\left(34.62 \mathrm{q} \mathrm{ha}^{-1}\right)$. The increase in number of umbels plant ${ }^{-1}$ could be attributed due to the increase in the number of both primary and secondary branches plant ${ }^{-1}$ with the application of Cycocel 300 ppm. The increase in number of umbellets per umbel by Cycocel might be due to accumulation of metabolites which get translocated towards the reproductive sinks and these in turn resulted in stimulation of umbellets. The increment in seed yield and biological yield was significantly higher in Cycocel which might be due to enhanced in growth and yield attributes. The above results were in conformity with the finding Meena et al., (2006), Kumar and Sundareswaran (2011), Vaidehi et al., (2015), Haokip et al., (2016), Yugandhar et al., (2016) in coriander.

Foliar application of $\mathrm{GA}_{3} 50$ ppm was recording the maximum test weight, while the minimum test weight was recorded with the control $\left(\mathrm{T}_{1}\right)$. Similar results were reported by Panda et al., (2007), Singh et al., (2012) in coriander and Meena et al., (2014) in fenugreek (Table 2).

\section{Quality parameters}

The results revealed that application of PGRs significantly improve quality parameters of coriander. Among different PGRs applied, $\mathrm{GA}_{3} 50$ ppm recorded significantly the maximum SPAD value (45.08), essential oil content in seed $(0.51 \%)$ and dry matter content in seed (90.80), while it was lowest with the control $\left(T_{1}\right)$. The increment in SPAD value, essential oil content in seed and dry matter content in seed may be due to the positive effect of $\mathrm{GA}_{3} 50 \mathrm{ppm}$ improved overall growth and metabolism and also the better translocation of carbohydrates and utilization by the plant for good growth. These findings are in close conformity with the findings of Verma and Sen (2008), Singh et al., (2012), Kuri et al., (2015), Vugandhar et al., (2016) and Haokip et al., (2016) in coriander.

The maximum benefit cost ratio was obtained with 50 ppm $\mathrm{GA}_{3}$ treatment, compared to other treatments.

\section{References}

Abbas, M.K. (2013). Effect of foliar fertilizer and some growth regulators on Vgetative and anatomical characters of dill (Anethum graveolens L.). Middle- East Journal of Scientific Research, 13(6): 803-811.

Bairva, M., Meena, S.S. and Mehta, R.S. (2012). 
Effect of bio-fertilizers and plant growth regulators on growth and yield of fenugreek (Trigonellafoenum- graecum L.). International Journal of Seed Spices, 2(1): 28-33.

Gour, K., Patel, B.S. and Mehta, R.S. (2010). Growth, yield and profitability of fenugreek (Trigonellafoenum-graecum L.) as influenced by varying levels of growth regulators and vermin-wash. Journal of Spices and Aromatic Crops, 19(1\&2): 6567.

Haokip, C. M., Sharangi, A. B., Debbarma, k., Devi, A. K. R. and Karthik, C. S. (2016). Role of plant growth regulators on the growth and yield of coriander (Coriandrum sativum L.). Journal of Crop and Weed, 12(3): 33-35.

Kumar, V.A. and Sundareswaran, S. (2011). Effect of foliar application of chemicals and growth regulator on growth and seed yield in coriander (Coriandrum sativum L.). Progressive Horticulture, 43(2): 193195.

Kuri, B. R., Jat, N. L., Shivran, A. C. and Puniya, M. M. (2015). Productivity and profitability of coriander varieties influence by sowing times and plant growth regulators. Ann. Agric. Res. New Series, 36(2): 204-211.

Meena, S. K., Jat, N.L., Sharma, B. and Meena, V. S. (2014). Effect of plant growth regulators and sulphur on productivity of coriander (Coriandrum sativum L.) in Rajasthan. International quarterly journal of environmental sciences, 6: 69-73.

Meena, S.S., Sen, N.L. and Malhotra, S.K. (2006). Influence of sowing date, nitrogen and plant growth regulators on growth and yield of coriander (Coriander sativumL.).
Journal of Spices and Aromatic Crops, 15(2): 88-92.

Panda, M.R., Chatterjee, R., Pariari, A., Chattopadhyay, P.K., Sharangi, A.B. and Alam, K. (2007). Effect of growth regulators on growth, yield and quality of coriander. Indian Journal of Horticulture, 64(3): 369-371.

Rohamare, Y., Nikam, T.D. and Dhumal, K.N. (2013). Effect of foliar application of plant growth regulators on growth, yield and essential oil components of ajwain (Trachyspermum ammi L.). International Journal of seed spices, 3(2): 34-41.

Singh, D., Singh, P.P., Naruka, I.S., Rathore, S.S. and Shaktawat, R.P.S. (2012). Effect of plant growth regulators on growth and yield of coriander. Indian Journal of Horticulture, 69(1): 91-93.

Vaidehi, G., Kumar, V. M. and Veeraragavathatham, V. (2015). Effect of plant growth regulators on different growth parameters and yield of coriander (Coriandrum sativum L.). International Journal of Tropical Agriculture, 33(2): 1523-1525.

Verma, P. and Sen, N.L. (2008). The impact of plant growth regulators on growth and biochemical constituents of coriander (Coriandrum sativumL.). Journal of Herbs, Spices \& Medicinal Plants, 14(3-4): 144153.

Yugandhar, V., Reddy, P. S. S., Sivaram, G. T. and Reddy, D. S. (2016). Influence of plant growth regulators on growth, seed yield, quality and economics of coriander (Coriandrum sativum L.) cv. Sudha. Journal of Spices and Aromatic Crops, 25(1):13-17.

\section{How to cite this article:}

Amit Kumar Kurmi, I.S. Naruka, S.S. Kushwah and Chouhan, G.S. 2019. Effect of PGRs on Growth, Yield and Quality of Coriander (Coriandrum sativum L.) cv. NRCSS-Acr-1. Int.J.Curr.Microbiol.App.Sci. 8(05): 2162-2167. doi: https://doi.org/10.20546/ijcmas.2019.805.255 